\title{
Arbuscular mycorrhizal fungus on the initial growth and nutrition of Coffea arabica L. genotypes
}

\section{Fungo micorrízico arbuscular no crescimento inicial e nutrição de genótipos de Coffea arabica L.}

\author{
Arley José Fonseca ${ }^{1} \mathbb{D}$, Ana Flávia de Freitas ${ }^{2 *}\left(\mathbb{D}\right.$, Gladyston Rodrigues Carvalho ${ }^{3} \mathbb{D}$, \\ Marco Aurélio Carbone Carneiro ${ }^{4}{ }^{-}$, Diego Júnior Martins Vilela ${ }^{5}$, Larissa de Oliveira Fassio ${ }^{6}$
}

\begin{abstract}
${ }^{1}$ Empresa de Pesquisa Agropecuária de Minas Gerais, Leopoldina, MG, Brasil
2Universidade Federal de Lavras/UFLA, Departamento de Agricultura/DAG, Lavras, MG, Brasil

3Empresa de Pesquisa Agropecuária de Minas Gerais-Sul, Campus UFLA, Lavras, MG, Brasil

${ }^{4}$ Universidade Federal de Lavras, UFLA, Departamento de Ciência do Solo, Lavras, MG, Brasil

${ }^{5}$ Empresa Agropecuária de Minas Gerais, Campo Experimental de Patrocínio, Patrocínio, MG, Brasil

${ }^{6}$ Federação dos Cafeicultores do Cerrado, Patrocínio, MG, Brasil

*Corresponding author: ninhadtna13@hotmail.com

Received in April 24, 2019 and approved in July 11, 2019
\end{abstract}

\begin{abstract}
The benefits of mycorrhization occur with the growth of hyphae in colonized roots by promoting an increase of the contact surface which improves the initial growth due to a better absorption of water and nutrients. The objective was to evaluate the effect of arbuscular mycorrhizal fungus Rhizophagus clarus inoculation over the initial development and nutritional response of six genotypes of Coffea arabica L. Six genotypes of Coffea arabica L. were used (MGS Aranas, H29-1-8-5, Red Catuai IAC 144, IPR 100, Catigua MG2, Paraíso H 419-1) and with arbuscular mycorrhizal fungus - AMF: Rhizophagus clarus and without the application of the fungus. For the production of coffee seedlings, seeds were placed to germinate in plastic trays with sterile sand. After germination, 10 seedlings of each genotype were transferred to $0.120 \mathrm{dm}^{3}$ polyethylene tubes with substrate. Then the inoculation of five seedlings of each genotype with the AMF $R$. Clarus was performed. When the seedlings with and without inoculation with the AMF presented six pairs of leaves they were transplanted to 13-liter pots containing soil (Dystrophic red-yellow latosol). The inoculation favored the initial growth of the coffee plants and its intensity varied according to the genotypes. The genotypes H 29-1-8-5, Red Catuai IAC 144 and Catigua MG 2 were the ones that presented higher shoot dry mass, root dry mass, total dry mass and accumulation of $P$, in relation to MGS aranãs, Paraiso H 419-1 and IPR 100, so they are the most promising to be inoculated with the arbuscular mycorrhizal fungus.
\end{abstract}

Index Terms: Coffee; mineral nutrition; progeny; fungal inoculation; symbiosis.

\section{RESUMO}

Os benefícios da micorrização ocorrem com o crescimento das hifas nas raízes colonizadas, promovendo uma ampliação da superfície de contato, aumento a absorção de água e nutrientes das raízes, facilitando crescimento inicial.Objetivou-se avaliar o efeito da inoculação fungo micorrizico arbuscular Rhizophagus clarus sobre o desenvolvimento inicial e a resposta nutricional de seis genótipos de Coffea arabica L. Foram utilizados seis genótipos de Coffea arabica L. (MGS Aranãs, H 29-1-8-5, Catuai vermelho IAC 144, Catiguá MG2, Paraíso H 419-1) com fungo micorrizico arbuscularFMA: Rhizophagus clarus e sem aplicação do fungo com cinco repetições. Para produção das mudas de café, sementes foram colocadas para germinar em bandeijas plásticas com areia estéril. Após a germinação 10 mudas de cada genótipo foram transferidas para tubos de polietileno de $0,120 \mathrm{dm}^{3} \mathrm{com}$ substrato. Nesse momento procedeu-se a inoculação de cinco mudas de cada genótipo com o FMA R. clarus. Quando as mudas de cafeeiro com e sem inoculação com o FMA apresentaram seis pares de folhas foram transplantadas para vasos de 13 litros, contendo solo (Latossolo Vermelho Amarelo Distrófico) esterilizado. A inoculação favoreceu o crescimento inicial das plantas de café e sua intensidade variou de acordo com os genótipos. Dos seis genótipos utilizados H 29-1-8-5, Catuai Vermelho IAC 144 e Catiguá MG 2 foram os que apresentaram maiores massa seca da parte aérea, massa seca das raízes, massa seca total e acúmulo do nutriente P, em relação ao MGS Aranãs, Paraiso H 419-1 e o IPR 100, sendo os mais promissores para serem inoculadas com fungo micorrízico arbuscular.

Termos para indexação: Café; nutrição mineral; progênie; inoculação fúngica; simbiose. 


\section{INTRODUCTION}

The species Coffea arabica $L$. stands out in the coffee production of Brazil, it has an area of around 1.50 million hectares planted and a production of 45 million sacks for the year of 2018. On the world stage, the coffee is among the most marketed products and profitable source of income for many countries (Consórcio Pesquisa Café, 2018). It has great importance for the economy, contributing positively to the Brazilian trade balance (Conab, 2018).

The growing demand for a higher quality product and on a large scale allows the use of several promising Brazilian coffee production techniques. One of them is the use of cultivars that are tolerant to adverse environmental conditions such as resistance to disease, improved quality, increased productivity and better use of nutrients (Albán; Guerrero; Toro, 2013). An alternative to it is the use of microorganisms of the soil as the arbuscular mycorrhizal fungus (AMF) during the production of seedlings, supporting a better establishment of the plant in the field and the production of beans (Beenhouweret et al., 2015).

The arbuscular mycorrhizal fungus, in agricultural systems, contributes to sustainability, as they present positive effects on functionalities and support the maintenance of natural ecosystems (Berude et al., 2015). It also benefits plants; especially when they grow in low fertility soils, as found in most tropical regions (Siqueira et al., 1998). This fungus-plant interaction promotes an increase of the contact surface, greater efficiency in the use of fertilizers and water, and improves the survival of seedlings in the field (Andrade; Silveira; Mazzafera, 2010). However, these benefits are dependent on the species, or isolated of, the AMF and edaphoclimatic conditions and the availability of the content of $P$ in the soil (Bhattacharya; Bagyaraj, 2002). Among the main measures for the use of AMF in plants of $C$. arabica $\mathrm{L}$. is the efficient fungal inoculation, able to colonizing quickly the roots of the coffee plant, generating positive responses to the plant (Konrad et al., 2014). Studying two coffee cultivars inoculated with the mycorrhizal arbuscular fungus species Gigaspora margarita and Glomus etunicatum in acid soils with a high concentration of $\mathrm{Al}$ and three levels of saturation per bases, it was observed an increase in height and in diameter of the stem in relation to the control (Konrad et al., 2014). Tristão, Andrade and Silveira (2006) evaluating coffee seedlings of Yellow Catuai IAC 62 inoculated with the AMF Glomus intraradices, Gigaspora margarita and Glomus etunicatum in different substrates, observed an increase in height of the shoot, the diameter of the collect, chlorophyll levels and accumulations of the nutrients $\mathrm{N}$ and $\mathrm{P}$. Some studies show the efficiency of AMF in coffee plants, mainly the Glomus and Gigaspora, the Rhizophagus clarus had positive responses from dry mass in coffee plants (Siqueira, et al., 1993; 1995).

The $C$. arabica $L$. features high response to the association of plant-fungus symbiosis, with benefits in the initial growth and mineral nutrition, especially the least mobile as $\mathrm{P}$, most preserved and most diverse in soil, and provides a favorable environment for the AMF community (Siqueira; Colozzi Filho, 1986; Siqueira, et al., 1993; Saggin-Júnior; Siqueira, 1995). So the objective was to evaluate the effect of inoculation arbuscular mycorrhizal fungus Rhizophagus clarus on the initial development and nutritional response of six genotypes of Coffea arabica $\mathrm{L}$.

\section{MATERIAL AND METHODS}

The experiment was conducted in nursery and greenhouse at the experimental station of the Agricultural Research Company of Minas Gerais (EPAMIG) at the Federal University of Lavras (UFLA), in Lavras, Minas Gerais, Brazil, in geographic coordinates $21^{\circ} 13^{\prime} 20.89^{\prime \prime}$ South and $44^{\circ} 58^{\prime} 05.51^{\prime \prime}$ West, altitude of 875 meters. The greenhouse had $25.5 \pm 3{ }^{\circ} \mathrm{C}$ temperature and average relative humidity of $60 \%$.

\section{Experimental arrangement and the origins of genotypes}

The experimental arrangement was in a Completely Randomized Design (CRD), in a $6 \times 2$ factorial scheme. The treatments were composed of six genotypes of Coffea arabica L. (MGS Aranas, H 29-1-8-5, Red Catuai IAC144, IPR 100, Catigua MG2, Paraiso H 419-1) in F6 generation) (Table 1) and with AMF: Rhizophagus clarus and without the inoculation of the fungus (control), with five repetitions and a plant per experimental unit. The genotypes were used according to their resistance to rust (Hemileia vastatrix) or nematodes (Meloidogyne sp.), good quality of drink and high productivity, selected from a population in development.

\section{Inoculant production}

For multiplication of AMF, it was used a substrate composed of soil (Dystrophic Red Latosol) and sand in the ratio of $1: 1(\mathrm{v}: \mathrm{v})$. The substrate was autoclaved to $120^{\circ} \mathrm{C}$, for 60 minutes, and this process repeated by completing 24 hours for sterilization. After 20 days, three-liter pots were filled with substrate and seeded with Brachiaria decumbens, inoculated with spores of $R$. clarus. After five months of inoculation with AMF, we quantified the spore density, taking $50 \mathrm{ml}$ soil samples of the pots and submitting to the wet extraction technique described by Gerdemann and Nilcolson (1963). 
Table 1: Origins of Coffea arabica L. genotypes used in the assay.

\begin{tabular}{cc}
\hline Genotypes & Genitors \\
\hline MGS Aranas & Red Icatu IAC 3851-2 x Catimor UFV 1602-215 \\
Progeny H 29-1-8-5 & Red Icatu IAC 2942 x Catimor UFV 1340 \\
Red Catuai IAC 144 & Yellow Caturra x IAC 476-11 x NewWorld IAC 374-19 \\
IPR 100 & Catuai x Genotype H7314-4 from series BA-10 \\
Catigua MG2 & Yellow Catuai IAC 86 x Timor Hybrid UFV 440-10 \\
Paraiso H 419-1 & Yellow Catuai IAC 30 x Timor Hybrid UFV 445-46 \\
\hline
\end{tabular}

\section{Production and inoculation of seedlings}

For the production of coffee seedlings, seeds were ceded in the experimental field of the EPAMIG in geographic coordinates $21^{\circ} 40^{\prime} 58.61^{\prime \prime}$ South and $45^{\circ}$ 56' 23.87" West, altitude of 791 meters, then placed to germinate in plastic trays with sterile sand. To reach the match stage "76 days after sowing", they were transferred to $0.120 \mathrm{dm}^{3}$ polyethylene tubes with charred pine bark substrate and vermiculite average expanded Vida Verde ${ }^{\circledR}$ (Tristão; Andrade; Silveira, 2006).

After germination, 10 seedlings of each genotype were transferred from the trays with sand to the tubes. Then, we proceeded to the inoculation with AMF $R$. clarus. We applied, $10 \mathrm{~g}$ soil inoculum containing spores, hyphae and colonized roots, with each seedling receiving the equivalent to 240 spores. The seedlings remained in the tubes for six months. During this period, the fertilization was done with slow-release fertilizer "osmocote Plus" 15-09-12, at a dose of $8 \mathrm{~g}$ per $\mathrm{dm}^{3}$.

\section{Transplanting of seedlings and substrate fertilization}

When the seedlings presented six pairs of leaves they were transplanted to 13 -liter pots containing soil (Dystrophic Red-Yellow Latosol) collected in 20-60 cm layer in an area used for expansion at UFLA in LavrasMG. The soil samples were seived on a $5 \mathrm{~mm}$ sieve and placed in bags containing $10 \mathrm{~kg}$ soil. It was moistened and autoclaved, remaining in the autoclave at a temperature of $120^{\circ} \mathrm{C}$ and $1 \mathrm{~atm}$ pressure for 1 hour, and the process repeated once again, with an interval of 1 day.

The phosphate fertilization - $80 \mathrm{mg} \mathrm{P}_{2} \mathrm{O}_{5} \mathrm{dm}^{-3}$ (superphosphate) was held in planting according to soil analysis performed at the Laboratory of Soil Fertility, in the Soil Science Department (UFLA). For fertilization, nitrogen and potassium were applied in three times, equivalent to $350 \mathrm{mg} \mathrm{N} \mathrm{dm}^{-3} \mathrm{~N}$ (urea) and $200 \mathrm{mg} \mathrm{K}_{2} \mathrm{O}$ $\mathrm{dm}^{-3}$ (potassium chloride), according to Guimarães et al.
(1999). The composted soil presented $\mathrm{pH}$ (in water) of 5.3; $57 \mathrm{mg} \mathrm{dm}^{-3} \mathrm{P} ; 101 \mathrm{mg} \mathrm{dm}{ }^{-3} \mathrm{~K}$, cmolc dm${ }^{-3} 3.1 \mathrm{Ca}$; $1.6 \mathrm{cmolc} \mathrm{dm}^{-3} \mathrm{Mg} ; 3.1 \mathrm{cmolc} \mathrm{dm}^{-3} \mathrm{H}+\mathrm{Al} ; 5.0 \mathrm{cmolc}$ $\mathrm{dm}^{-3} \mathrm{SB} ; 61.5 \% \mathrm{~V}$ and $32.8 \mathrm{~g} \mathrm{~kg}^{-1}$ organic matter.

At the time of transplanting the seedlings for the pots, measurements were carried out from the height of the shoot and the stem diameter. The soil was kept moist with the addition of 0.490 liters of filtered water per pot, with daily watering shift, with an automatic dripping system. The control of weeds and pests was performed manually and the control of diseases, according to the recommendations for the culture.

\section{Evaluations of the experiment}

After five months, the height of the shoot and the diameter of the stem were measured. At the end of the period of 10 months, the characteristics were measured, obtaining the increments in the height of the shoot and stem diameter.

At the $300^{\text {th }}$ day the foliar area was evaluated (Huerta, 1962), and also collected the shoot and roots. The roots were washed in running water for removal of the substrate then 1 gram of 1 to $2 \mathrm{~cm}$ fragments were stored in $70 \%$ alcohol solution for subsequent determination of the percentage of colonized roots (Giovannetti; Mosse, 1980). The rest of the roots and shoots were dried in a forced air circulation oven at $65^{\circ} \mathrm{C}$ for the determination of root dry mass (MSR), shoot dry mass (MSPA) and total dry mass (MST), and calculation of the relative response to inoculation. The inoculation was calculated by the following formula, $\mathrm{RI}=[$ (dry mass of roots of mycorrhized plants) - (dry mass of roots of not inoculated plants)/dry mass of roots of inoculated plants] x 100 .

The shoot of plants after determining the MSPA was milled in mill type Willey with 40 mesh sieve. Then it was digested in sulfuric solution for the determination of $\mathrm{N}$ with the micro Kjeldahl method (distillation) and nitro-perchloric solution $2: 1(\mathrm{v}: \mathrm{v})$ for the extraction of 
$\mathrm{P}$ and $\mathrm{K}$ in the shoot of plants. The content of $\mathrm{P}$ was determined by colorimetry and the content of $\mathrm{K}$ was determined by flame photometer(Malavolta; Vitti; Oliveira, 1997). The accumulation of N, P, and K was calculated by multiplying the concentration of nutrients in the shoot by MSPA.

\section{Statistical analyses}

The data were analyzed in relation to normality and homogeneity of variances. The data of the diameter of the stem, shoot dry mass, root dry mass, total dry mass, percentage of colonized roots, leaf area and the accumulation of $\mathrm{N}, \mathrm{P}$, and $\mathrm{K}$ were transformed by multiplying by $\ln (\mathrm{x}+2)$, for not following a normal distribution. Then the variables were submitted to analysis of variance for the $5 \% \mathrm{~F}$ test of significance and the means of the treatments compared by Scott \& Knott, at the $5 \%$ level of significance. Correlation analysis was determined between the variables, considering a 5\% level of significance through the Pearson test. All statistical analyses were performed with the computer program system - Sisvar (Ferreira, 2008) and with the SAS program (SAS, 1999), version 9.1.

\section{RESULTS AND DISCUSSION}

The analyzed variables and the mean square with its significance are presented below (Table 2).

The height increment of the shoot to 150 and 300 days, was influenced by the inoculation with AMF. At 150 days, the plants inoculated with the AMF R. clarus (Figure 1) showed an increase of $11.6 \%$ in relation to the control (non-inoculated seedlings). On the other hand, at 300 days, the increase in the height of the aerial part for plants inoculated with AMF $R$. clarus (Figure 1) was 9.5\% in relation to the control. Several studies have observed an increase in height of the shoot of $C$. arabica $L$. for species or isolated of arbuscular mycorrhizal fungi (Bhattacharya; Bagyaraj, 2002; Konrad et al., 2014).

The increment in the diameter of the stem of the coffee plants at the $150^{\text {th }}$ and $300^{\text {th }}$ day was influenced by the inoculation with $\mathrm{AMF}$ and was dependent on the genotypes. For increment in the diameter of the stem at the $150^{\text {th }}$ day, the cultivars Red Catuai IAC 144, IPR 100 and Catigua MG 2, inoculated with $R$. clarus (Table 3), there was an increase of $88.5 ; 99.2$ and $35.4 \%$ respectively, as compared to the non-inoculated plants (control). At the $300^{\text {th }}$ day the genotypes MGS Aranas, progeny H 29-1-8-5, Red Catuai IAC 144, IPR 100 and Catigua MG 2, inoculated with $R$.

Table 2: Mean square and significance, obtained in the analysis of variance of the data collected on the assessment of height increment, diameter increment, shoot dry mass, root dry mass, total dry mass, leaf area, percentage of colonization, content of nutrients N, P, and K for plants of six genotypes of Coffea arabica L. with and without inoculation of arbuscular mycorrhizal fungus in greenhouse test.

\begin{tabular}{|c|c|c|c|c|}
\hline \multicolumn{5}{|c|}{ Source of variation } \\
\hline Variables & Fungus (F) & Genotypes (G) & $F \times G$ & CV. \% \\
\hline \multicolumn{5}{|c|}{ 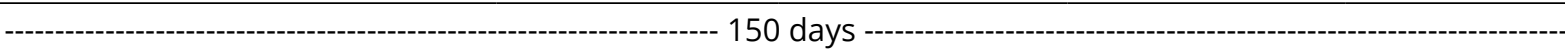 } \\
\hline Height increment & $186.208^{* \star}$ & 9.885 & 12.963 & 12.2 \\
\hline Stem diameter increment & $10.039 * \star$ & 2.008 & $9.811 * \star$ & 20.9 \\
\hline \multicolumn{5}{|c|}{ 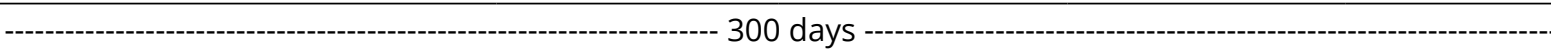 } \\
\hline Height increment & $439.563 * *$ & 7.022 & 31.584 & 12.4 \\
\hline Stem diameter increment & $0.897 * \star$ & $0.119 * *$ & $0.045^{*}$ & 9.6 \\
\hline Shoot dry mass & $3.322 * *$ & 0.086 & $0.309 * *$ & 5.7 \\
\hline Root dry mass & $4.841 * *$ & 0.271 & 0.776 ** & 13.9 \\
\hline Total dry mass & $4.749 * *$ & 0.144 & $0.463 * *$ & 6.4 \\
\hline Leaf area & $0.428 * *$ & 0.018 & $0.045 * *$ & 8.0 \\
\hline Colonization percentage & $138.290 * *$ & 0.090 & $0.135^{*}$ & 10.4 \\
\hline Accumulation of $\mathrm{N}$ & $0.080 * *$ & 0.040 & $0.124 * *$ & 10.1 \\
\hline Accumulation of $\mathrm{P}$ & $0.015^{* *}$ & 0.002 & $0.002 *$ & 3.8 \\
\hline Accumulation of $\mathrm{K}$ & $0.472 * *$ & $0.044 * *$ & $0.058 * *$ & 9.5 \\
\hline
\end{tabular}

* = significant to $5 \%$; ** = significant to $1 \%$. 
clarus (Table 2), there was an increase of $45.9 ; 53.5 ; 48.4$; 66.8 and $39.3 \%$ in relation to the non-inoculated plants (control). In the work of Rodrigues, Barroso and Figueiredo (2018), the incidence of $R$. clarus fungus produced a significant increase of $80 \%$ in biomass and $45 \%$ in height of the plants, when compared to the control.

Corroborating with this work, Konrad et al. (2014) in a study with three levels of saturation per bases, two cultivars of $C$. arabica $L$. and two species of arbuscular mycorrhizal fungi G. margarita and Glomus etunicatum in acid soils with high $\mathrm{Al}$ concentration had an increase in height and diameter of stem of inoculated seedlings in relation to the non-inoculated control.

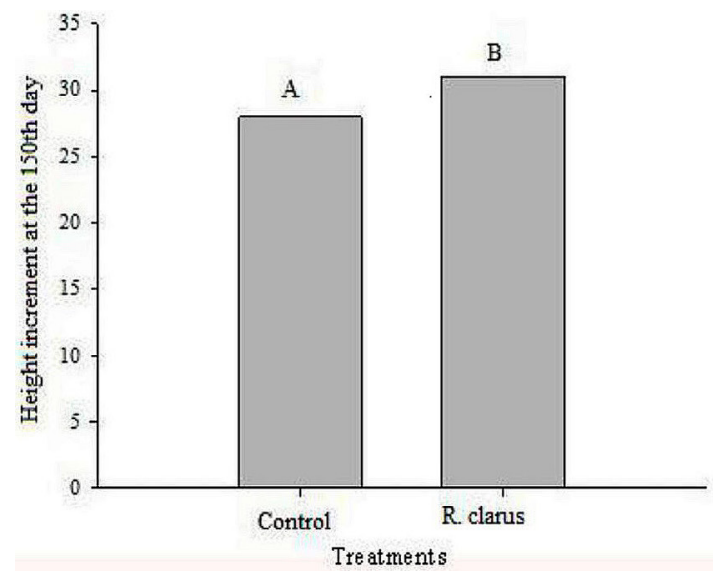

It was observed a great response to the interaction genotype $x$ fungi on leaf area, in the dry mass from the shoot, root system and total, with the influence of the colonization with AMF on the genotypes. The leaf area was influenced by fungi, and was dependent on the genotypes (Table 4). For leaf area, the cultivars Red Catuai IAC 144, IPR 100 and Catigua MG 2 inoculated with the fungus showed an increase compared to the control plants, with a minimum increase of $53.5 \%$. The total dry mass and the leaf area presented similar influence to this interaction, with emphasis on the cultivars Red Catuai IAC 144 and IPR 100, when inoculated with AMFR. clarus.

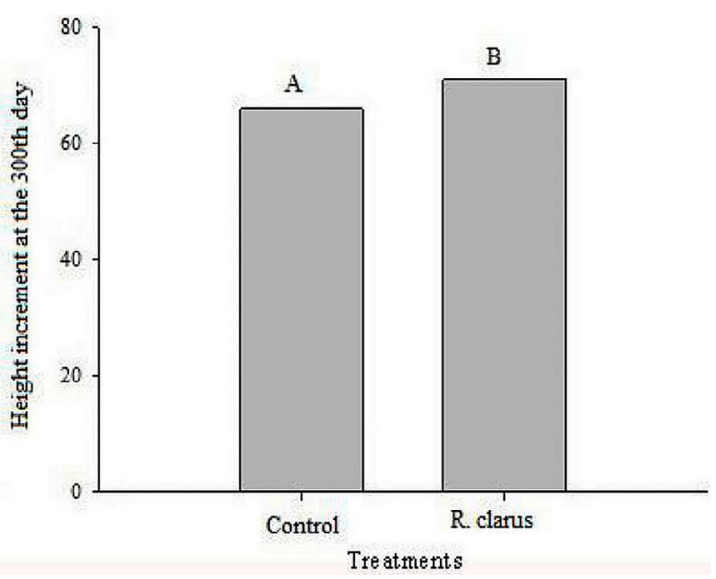

Figure 1: Graphical representation of the average increase of height in plants of six genotypes of Coffea arabica L. to 150 and 300 days, with and without inoculation of arbuscular mycorrhizal fungi on assay installed in a greenhouse.

Table 3: The increment of stem diameter in plants of six genotypes of Coffea arabica L. to 150 and 300 days with and without inoculation of arbuscular mycorrhizal fungi on assay installed in a greenhouse.

\begin{tabular}{|c|c|c|c|c|}
\hline \multirow[b]{2}{*}{ Genotypes } & \multicolumn{2}{|c|}{$\begin{array}{c}\text { Stem diameter increment } \\
\text { (150 days) }\end{array}$} & \multicolumn{2}{|c|}{$\begin{array}{c}\text { Stem diameter increment } \\
\text { (300 days) }\end{array}$} \\
\hline & Control & R. clarus & Control & R. clarus \\
\hline & \multicolumn{2}{|c|}{ 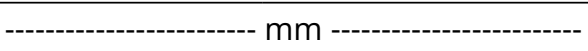 } & \multicolumn{2}{|c|}{ 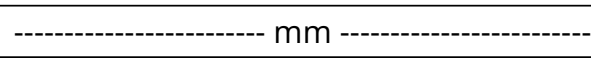 } \\
\hline ARANAS & $6.27 \mathrm{Aa}^{1 /}$ & $4.78 \mathrm{Bb}$ & 3.81Ba & $5.56 \mathrm{Ab}$ \\
\hline H 29-1-8-5 & $5.15 \mathrm{Aa}$ & $5.48 \mathrm{Ab}$ & $4.52 \mathrm{Ba}$ & 6.94Aa \\
\hline C. IAC 144 & $3.96 \mathrm{Bb}$ & $7.46 \mathrm{Aa}$ & 3.73Ba & $5.54 \mathrm{Ab}$ \\
\hline IPR 100 & $3.33 \mathrm{Bb}$ & $6.64 \mathrm{Aa}$ & $4.55 \mathrm{Ba}$ & 7.59Aa \\
\hline C. MG 2 & $4.20 \mathrm{Bb}$ & $5.68 \mathrm{Ab}$ & 3.49Aa & $4.86 \mathrm{Ab}$ \\
\hline PARAISO & $4.55 \mathrm{Ab}$ & 4.40Ab & $4.10 \mathrm{Aa}$ & $4.04 \mathrm{Ab}$ \\
\hline $\mathrm{CV}^{12} . \%$ & \multicolumn{2}{|c|}{20.9} & \multicolumn{2}{|c|}{9.6} \\
\hline
\end{tabular}

$1 /$ Means followed by equal uppercase letters in the row and lowercase letters in the column for each variable do not differ by Scott \& Knott 5\% level of significance. 2/ Variation coefficient. 
Table 4: Leaf area, shoot dry mass, root dry mass and total dry mass of plants of six genotypes of Coffea arabica $L$. with and without the inoculation of arbuscular mycorrhizal fungi on assay installed in a greenhouse.

\begin{tabular}{|c|c|c|c|c|}
\hline \multirow[b]{2}{*}{ Genotypes } & \multicolumn{2}{|c|}{ Leaf area } & \multicolumn{2}{|c|}{ Shoot dry mass } \\
\hline & Control & R. clarus & Control & R. clarus \\
\hline & \multicolumn{2}{|c|}{ - } & \multicolumn{2}{|c|}{------------------ grams ----------------- } \\
\hline ARANAS & $0.82 \mathrm{Aa}^{1 /}$ & $1.08 \mathrm{AC}$ & $89.53 \mathrm{Aa}$ & $113.25 \mathrm{Ab}$ \\
\hline H 29-1-8-5 & $0.90 \mathrm{Ba}$ & $1.38 \mathrm{Ab}$ & 89.78Ba & $142.01 \mathrm{Aa}$ \\
\hline C. IAC 144 & 0.87Ba & 1.67Aa & $90.92 \mathrm{Ba}$ & $175.86 \mathrm{Aa}$ \\
\hline IPR 100 & $0.67 \mathrm{Ba}$ & $1.79 \mathrm{Aa}$ & $69.26 \mathrm{Ba}$ & 172.67Aa \\
\hline C. MG 2 & $0.81 \mathrm{Ba}$ & $1.30 \mathrm{Ab}$ & $72.63 \mathrm{Ba}$ & $130.61 \mathrm{Aa}$ \\
\hline PARAISO & $1.00 \mathrm{Aa}$ & $0.89 A c$ & $102.09 \mathrm{Aa}$ & $103.93 \mathrm{Ab}$ \\
\hline \multirow[t]{3}{*}{$\mathrm{CV}^{12} . \%$} & \multicolumn{2}{|c|}{8.0} & \multicolumn{2}{|c|}{5.7} \\
\hline & \multicolumn{2}{|c|}{ Root dry mass } & \multicolumn{2}{|c|}{ Total dry mass } \\
\hline & \multicolumn{2}{|c|}{ 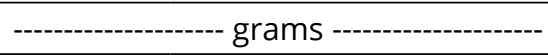 } & \multicolumn{2}{|c|}{ 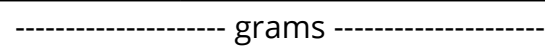 } \\
\hline ARANAS & $31.5 \mathrm{Aa}$ & $37.0 \mathrm{Ab}$ & 121.0Aa & $150.3 \mathrm{Ab}$ \\
\hline H 29-1-8-5 & $22.0 \mathrm{Bb}$ & 75.6Aa & 111.8Ba & 217.6Aa \\
\hline C. IAC 144 & $25.9 \mathrm{Bb}$ & $119.5 \mathrm{Aa}$ & 116.9Ba & 295.3Aa \\
\hline IPR 100 & $19.2 \mathrm{Bb}$ & $49.5 \mathrm{Ab}$ & $88.4 \mathrm{Ba}$ & 222.2Aa \\
\hline C. MG 2 & $13.4 \mathrm{Bb}$ & $55.8 \mathrm{Ab}$ & 86.0Ba & 186.4Ab \\
\hline PARAISO & $42.2 \mathrm{Aa}$ & $45.5 \mathrm{Ab}$ & 144.3Aa & 149.5Ab \\
\hline $\mathrm{CV}^{12} . \%$ & \multicolumn{2}{|c|}{13.9} & \multicolumn{2}{|c|}{6.4} \\
\hline
\end{tabular}

$1 /$ Means followed by equal uppercase letters in the row and lowercase letters in the column for each variable do not differ by Scott \& Knott $5 \%$ level of significance.2/ Variation coefficient.

The shoot dry mass, root dry mass, and total dry mass were influenced by fungi, and this effect was dependent on the cultivars (Table 4). For the shoot dry mass, the cultivars Red Catuai IAC 144, IPR 100, Catigua MG 2 and the progeny H 29-1-8-5 inoculated with the AMFR. clarus (Table 3) showed an increase of 93.4; $149.3 ; 79.8$ and $58.2 \%$ respectively, as compared to the non-inoculated plants (control).

The dry mass of roots presented the influence of colonization with AMF on Red Catuai IAC 144, IPR 100, Catigua MG2 and progeny H 29-1-8-5 (Table 3). In these genotypes inoculated with AMF $R$. clarus, the increase was of $360.6 ; 158.3 ; 317.0$ and $244.3 \%$ respectively, as compared with the non-inoculated plants (control). These results are very important in demonstrating how much the coffee plants can benefit from the symbiosis, and corroborate with some authors that the inoculation of the AMF increases dry mass from the shoot and roots (Siqueira et al., 1993).

The total dry mass of plants, of all the genotypes, when inoculated with $R$. clarus AMF (Table 3), increased satisfactorily, except for cultivars MGS Aranas and Paraiso H 419-1. The cultivar Red Catuai IAC 144 when inoculated with the AMF $R$. clarus, stood out among the others, in relation to the shoot dry mass, root dry mass, and total dry mass. In this way, the parameters of growth in height and diameter of the stem, and root dry mass were benefited by the inoculation of the AMF and presented great effect when compared to the control. Similar results were observed for AMF alone or in combinations of fungi (Saggin Júnior et al., 1995; Siqueira et al., 1993).

This information about the efficiency of the AMF to promote the increase of dry mass of the coffee plants is very important because their crops are carried out in areas poor in some nutrients, particularly phosphorus. In this sense, the possibility of using mycorrhized seedlings to contribute to better nutrition for them in the field, increase the rate of methods and improve resistance to water stress.

The percentage of colonized roots was influenced by the AMF and this effect was dependent on the 
genotypes (Table 5). The six cultivars inoculated with FMA had higher colonization in the plants compared to the control. The plants showed on average a colonization ranging from 34 to $62 \%$ and there was no colonization in control treatments.

In work done with Yellow Catuai IAC 62, seedlings inoculated with AMF Glomus intraradices, Glomus etunicatum, and Gigaspora margarita in commercial substrate without fertilization, they presented a good percentage of colonized roots, however with percentages below the present work (Tristão; Andrade; Silveira, 2006).

Some works with different genetic materials of coffee plants inoculated with AMF showed variation in the percentage of colonized roots with the influence of environment and soil and edafoclimatic conditions (Alban; Guerrero; Toro, 2013; Berbara et al., 2006). It is important to mention this symbiosis relationship is obligatory for the fungus, whereas for its hosts it is optional, although there are indications of obligate myotrophism by some plant species (Mohan et al., 2014).
Several authors have verified the potential of positive gains with the use of AMF in plants of C. Arabica L. (Maia; Silveira; Cavalcante, 2006; Tristão; Andrade; Silveira, 2006). Konrad et al. (2014), studying two coffee cultivars inoculated with the mycorrhizal fungi species G. margarita and Glomus etunicatum in acid soils with a high concentration of $\mathrm{Al}$ and three levels of saturation per bases, it was observed an increase in height and diameter of the stem in relation to the control. Mycorrhized coffee seedlings with AMF showed higher levels of $\mathrm{P}$ and $\mathrm{Cu}$ in relation to the non-mycorrhized ones (Siqueira; Colozzi Filho, 1986; Saggin Júnior; Siqueira, 1995).

The nutrient accumulations were influenced by fungi, and this effect was dependent on the genotypes (Table 5). The accumulation of $\mathrm{N}$ in the shoot of plants of cultivars Red Catuai IAC 144, IPR 100, Catigua MG 2 and progeny H 29-1-8-5 with the AMF $R$. clarus was respectively of $55.4 ; 197.5 ; 75.8$ and $52.3 \%$ superior to the control (Table 5). Among the genotypes inoculated with the AMF $R$. clarus the cultivars Red Catuai IAC 144 and IPR 100 stood out in the accumulation of nitrogen.

Table 5: Percentage of colonization of roots and accumulation of N, P and K of plants of six genotypes of Coffea arabica L. with and without inoculation of arbuscular mycorrhizal fungi on assay installed in a greenhouse.

\begin{tabular}{|c|c|c|c|c|}
\hline \multirow[b]{2}{*}{ Genotypes } & \multicolumn{2}{|c|}{ Percentage of colonized roots } & \multicolumn{2}{|c|}{ Accumulation of $\mathrm{N}$} \\
\hline & Control & R. clarus & Control & R. clarus \\
\hline & \multicolumn{2}{|c|}{--------------- \% ---------------- } & \multicolumn{2}{|c|}{--------- grams per plant -------- } \\
\hline ARANAS & $0.00 \mathrm{Ba}$ & 40.83Aa & 2.76Aa & $3.38 \mathrm{Ab}$ \\
\hline H 29-1-8-5 & $0.00 \mathrm{Ba}$ & 47.69Aa & $2.60 \mathrm{Ba}$ & $3.96 \mathrm{Ab}$ \\
\hline C. IAC 144 & $0.00 \mathrm{Ba}$ & 61.72Aa & 3.05Ba & 4.74Aa \\
\hline IPR 100 & $0.00 \mathrm{Ba}$ & 41.43Aa & $1.57 \mathrm{Bb}$ & 4.67Aa \\
\hline C. MG 2 & $0.00 \mathrm{Ba}$ & 46.16Aa & $2.11 \mathrm{Bb}$ & $3.71 \mathrm{Ab}$ \\
\hline PARAISO & $0.00 \mathrm{Ba}$ & $31.98 \mathrm{Ab}$ & 3.05Aa & $2.83 \mathrm{Ab}$ \\
\hline \multirow[t]{3}{*}{$\mathrm{CV}^{12} . \%$} & \multicolumn{2}{|c|}{8.0} & \multicolumn{2}{|c|}{10.1} \\
\hline & \multicolumn{2}{|c|}{ Accumulation of $\mathrm{P}$} & \multicolumn{2}{|c|}{ Accumulation of $\mathrm{K}$} \\
\hline & \multicolumn{2}{|c|}{--------------- grams per plant --------------- } & \multicolumn{2}{|c|}{-------- grams per plant -------. } \\
\hline ARANAS & $0.23 \mathrm{Aa}$ & $0.25 \mathrm{Ab}$ & $1.31 \mathrm{Aa}$ & $1.28 \mathrm{Ab}$ \\
\hline H 29-1-8-5 & $0.22 \mathrm{Ba}$ & $0.32 \mathrm{Aa}$ & $1.36 \mathrm{Aa}$ & $1.84 \mathrm{Ab}$ \\
\hline C. IAC 144 & $0.25 \mathrm{Ba}$ & $0.33 \mathrm{Aa}$ & 1.45Ba & 2.60Aa \\
\hline IPR 100 & $0.21 \mathrm{Ba}$ & $0.34 \mathrm{Aa}$ & 1.10Ba & $2.48 \mathrm{Aa}$ \\
\hline C. MG 2 & $0.17 \mathrm{Ba}$ & $0.29 A a$ & 0.99Ba & $1.65 A b$ \\
\hline PARAISO & $0.26 \mathrm{Aa}$ & $0.21 \mathrm{Ab}$ & $1.54 \mathrm{Aa}$ & $1.28 \mathrm{Ab}$ \\
\hline $\mathrm{CV}^{12} . \%$ & \multicolumn{2}{|c|}{13.9} & \multicolumn{2}{|c|}{6.4} \\
\hline
\end{tabular}

$1 /$ Means followed by equal uppercase letters in the row and lowercase letters in the column for each variable do not differ by Scott \& Knott $5 \%$ level of significance. 2/ Variation coefficient. 
There was an accumulation of $\mathrm{P}$ in plants of varieties IPR 100, Catigua MG2 and progeny H 29-1-8-5 and when inoculated with the AMF (Table 5), showed an increase of $61.9 ; 70.6$ and $45.5 \%$ respectively, compared to the control (Table 5). In addition to $\mathrm{P}$ acquisition, FMAs contribute to the greater absorption of other nutrients. The $R$. clarus presented an increase of 26.7 $\%$ for the content of $\mathrm{K}$, in relation to the control (Brito et al., 2017) as found in this work.

The accumulation of $\mathrm{K}$ was higher in the cultivars IPR 100 and Catigua MG 2 when inoculated with R. clarus (Table 5). Coffee plants with and without inoculation of AMF showed no visual symptoms of nutrient deficiency. Some studies corroborate with the observed, in which several species, and/or, isolates of AMF increased absorption of phosphorus and nitrogen (Hodge; Campbell; Fitter, 2001; Siqueira et al., 1998; Tristão; Andrade; Silveira, 2006). So it is clear the direct benefits of arbuscular mycorrhizal fungi in coffee plants in the absorption of nutrients from the soil, reflecting on their growth.

The inoculation with $R$. clarus for root dry mass was higher in all genotypes MGS Aranas, progeny $\mathrm{H}$ 29-1-8-5, Red Catuai IAC 144, IPR 100, Catigua MG2, progeny H 29-1-8-5 and Paraiso H 419-1 (Figure 2). The high efficiency of the inoculated fungus can be associated with a high potential of inoculation in genotypes, which can present favorable results to the coffee plants as higher initial growth, being influenced by various biotic and abiotic factors (Costa et al., 2005). The relation to the inoculation indicates a possible success in the inoculation in genotypes of $C$. arabica $\mathrm{L}$. in this way, the excellent value found for a response to the inoculation of the AMF in this essay indicates that some fungi can be employed for inoculation of some coffee cultivars (Saggin Junior; Siqueira, 1995). These decreases in the cultivars MGS Aranas and Paraiso H 419-1, can be considered normal due to the inhibition of the establishment of the symbiosis when subjected to high levels of $\mathrm{P}$ in the soil, with reduced colonization of roots (Moreira; Siqueira, 2006).

The correlation was significant and positive in most of the variables, but some with higher magnitudes. In the percentage of colonized roots it was observed the highest correlations among all the variables height, stem diameter, shoot dry mass, root dry mass, total dry mass, leaf area and accumulations of N, P and K (Table 6).

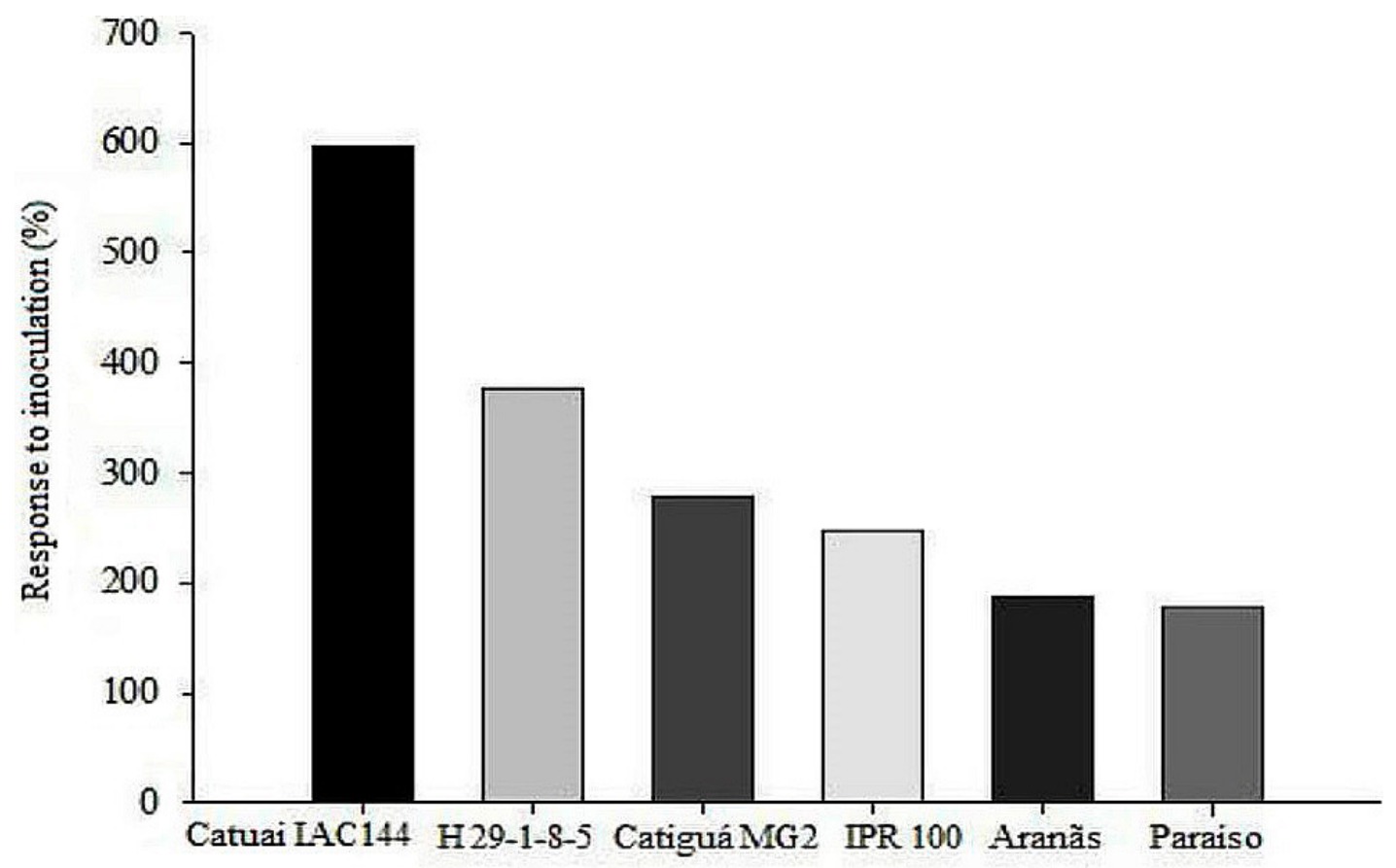

\section{Genotypes}

Figure 2: Graphical representation of the response to the inoculation with R. clarus for roots dry mass of plants of six genotypes of Coffea arabica L. in assay installed in a greenhouse, Lavras-MG. 
Table 6: Correlation between percentage of colonization, height, stem diameter, shoot dry mass, root dry mass, total dry mass, leaf area, total accumulation of N, P and K for coffee plants, with and without the use of AMF in assay installed vegetation house at the $300^{\text {th }}$ day, Lavras-MG.

\begin{tabular}{|c|c|c|c|c|c|c|c|c|c|}
\hline Correlation & $\begin{array}{c}\% \text { of } \\
\text { colonization }\end{array}$ & Height & $\begin{array}{c}\text { Stem } \\
\text { diameter }\end{array}$ & $\begin{array}{c}\text { Shoot } \\
\text { dry mass }\end{array}$ & $\begin{array}{c}\text { Root dry } \\
\text { mass }\end{array}$ & $\begin{array}{l}\text { Total dry } \\
\text { mass }\end{array}$ & $\begin{array}{l}\text { Leaf } \\
\text { area }\end{array}$ & $\begin{array}{c}\text { Accumulation } \\
\text { of } \mathrm{N}\end{array}$ & $\begin{array}{c}\text { Accumulation } \\
\text { of } P\end{array}$ \\
\hline Height & $0.81 * \star$ & & & & & & & & \\
\hline Stem diameter & $0.72 *$ & $0.79 * *$ & & & & & & & \\
\hline $\begin{array}{l}\text { Shoot dry } \\
\text { mass }\end{array}$ & $0.88^{* *}$ & $0.85^{* *}$ & $0.81 * \star$ & & & & & & \\
\hline Root dry mass & $0.80 * *$ & $0.71 * *$ & $0.54 \mathrm{~ns}$ & $0.85^{* \star}$ & & & & & \\
\hline Total dry mass & $0.86^{* *}$ & $0.82 * *$ & $0.72 * \star$ & $0.97 * \star$ & $0.95 * *$ & & & & \\
\hline Leaf area & $0.83 * *$ & $0.84^{* *}$ & $0.84 * *$ & $0.99 * *$ & $0.80 * *$ & $0.94 * *$ & & & \\
\hline $\begin{array}{c}\text { Accumulation } \\
\text { of } N\end{array}$ & $0.82^{* *}$ & $0.79 * *$ & $0.74 * \star$ & $0.97^{* \star}$ & $0.82 * *$ & $0.94^{* *}$ & $0.96 * \star$ & & \\
\hline $\begin{array}{c}\text { Accumulation } \\
\text { of } P\end{array}$ & $0.75^{* *}$ & $0.76^{* \star}$ & $0.79 * *$ & $0.96 * *$ & $0.85^{* *}$ & $0.95^{* *}$ & $0.96 * *$ & $0.94^{* *}$ & \\
\hline $\begin{array}{c}\text { Accumulation } \\
\text { of } K\end{array}$ & $0.78 * *$ & $0.80 * *$ & $0.78^{* *}$ & $0.97^{* \star}$ & $0.82 * *$ & $0.94 * *$ & $0.96 * *$ & $0.95 * *$ & $0.95^{* *}$ \\
\hline
\end{tabular}

Significant * and ** 5 and $1 \%$ respectively, ns non-significant by Pearson test.

Generally, the percentage of colonization is highly correlated with the amount of $\mathrm{P}$ in the shoot, which is dependent on the concentration in the soil. In soils with high levels of $\mathrm{P}$, it causes inhibition of the colonization rate, due to a good nutritional status of the plant and the regulatory mechanisms of symbiosis (Moreira; Siqueira, 2006). When the plants are in symbiosis with the AMF, they exhibit good nutrition, so they demonstrate adaptive advantages after being planted on the field, with higher survival rate and initial growth (Siqueira et al., 1995).

So we can observe that the inoculation of the genotypes of coffee plants with the AMF R. clarus, provided an improvement in all the analyzed variables as height, stem diameter, leaf area, dry mass, and nutrient accumulations. These increases are evident in the cultivars Red Catuai IAC 144 and Catigua MG 2, which showed good development when in the presence of AMF, enabling the use of the technique of inoculation for future plantings in areas with low availability of nutrients or with water deficit. Plant establishment and development are associated with mycorrhizal. Mycorrhizal plants have more efficient nutritional strategies than non-mycorrhizal plants, benefiting survival under stress (Mergulhão et al., 2014).

With the commercial production of inoculants of $\mathrm{AMF}$, it will be possible to improve the settlement of the seedlings in the field at times or in regions with higher water deficit and the formation of coffee plantations, becomes an accessible technology to the Brazilian coffee farmers.

\section{CONCLUSIONS}

The inoculation favored the initial growth of the coffee plants and the intensity varied according to the genotypes. The genotypes H 29-1-8-5, Red Catuai IAC 144 and Catigua MG 2 were the ones that presented higher shoot dry mass, root dry mass, total dry mass and accumulation of $\mathrm{P}$, being more responsive when inoculated with the AMF, among the six genotypes studied. In all the variables studied, when the plants were inoculated with the mycorrhizal fungus Rhizophagus clarus, it showed gains in relation to the non-inoculated plants.

\section{ACKNOWLEDGMENTS}

The authors gratefully acknowledge FAPEMIG for the financial support, $\mathrm{CNPq}$ for the productivity scholarship (GRC and MACC), CAPES, INCT, and Consórcio Pesquisa Café.

\section{REFERENCES}

ALBÁN, R.; GUERRERO, R.; TORO, M. Interactions between a root knot nematode (Meloidoyne exigua) and arbuscular mycorrhizae in coffee plant development (Coffea arabica). American Journal of Plant Sciences, 4(7):19-23, 2013. 
ANDRADE, S. A. L.; SILVEIRA, A. P. D.; MAZZAFERA, P. Arbuscular mycorrhiza alters metal uptake and the physiological response of Coffea arabica seedlings to increasing $\mathrm{Zn}$ and $\mathrm{Cu}$ concentrations in soil. Science of the Total Environment, 408(22):5381-5391, 2010.

BEENHOUWER, M. et al. DNA pyrosequencing evidence for large diversity differences between natural and managed coffee mycorrhizal fungal communities. Agronomy for Sustainable Development, 35(1):241-249, 2015.

BERBARA, R. L. L.; SOUZA, F. A.; FONSECA, H. M. A. C. Fungos micorrízicos arbusculares: Muito além da nutrição. In: FERNANDES, M. S. (Ed.). Nutrição mineral de $\mathbf{6 1 2}$ plantas. Viçosa, MG: Sociedade Brasileira de Ciência do Solo, 2006. p.74-85.

BERUDE, M. C. et al. Micorrizas e suas importância agroecológica. Enciclopédia Biosfera, 11(22):132, 2015.

BHATTACHARYA, S.; BAGYARAJ, D. J. Effectiveness of arbuscular mycorrhizal fungal isolates on arabica coffee (Coffea Arabica L.). Biologia Agriculture and Horticulture, 20(2):125-131, 2002.

BRITO, V. N. et al. Fungos micorrizicos arbusculares e adubação fosfatada na produção de mudas de paricá. Ciência Florestal, 2(27):485-497, 2017.

COMPANHIA NACIONAL DE ABASTECIMENTO - CONAB. Levantamento CONAB da safra de café. Brasília, DF: Conab, 2018. Available in: <http://www.sapc.embrapa. br/arquivos/consorcio/levantamento/conab_safra2018_ n1.pdf >. Access in: February, 20, 2019.

CONSÓRCIO PESQUISA CAFÉ. 2018. Available in: <http://www. consorciopesquisacafe.com.br/index.php/imprensa/ noticias/878-2018-08-01-20-31-50>. Access in: July, 22, 2019.

COSTA, C. M. C. et al. Fungos micorrízicos arbusculares e adubação fosfatada em mudas de mangabeira. Pesquisa Agropecuária Brasileira, 40(3):225-232, 2005.

FERREIRA, D. F. SISVAR: Um programa para análises e ensino de estatística. Revista Científica Symposium, 6(4):3641, 2008.

GERDEMANN, J. W.; NICOLSON, T. H. Spores of mycorrhizalendogone species extracted from soil by wet-sieving and decanting.Transactions of the British Mycological Society, 46(2):235-244, 1963.

GIOVANNETTI, M.; MOSSE, B. An evaluation of techniques for measuring vesicular-arbuscular mycorrhizal infection in roots. New Phytologist, 84:489-500, 1980.
GUIMARÃES, P. T. G. et al. Cafeeiro. In: RIBEIRO, A. C. et al. Recomendações para o uso de corretivos e fertilizantes em Minas Gerais: $5^{\text {a }}$ aproximação. Viçosa: CFSEMG, 1999. p.289-302.

HODGE, A.; CAMPBELL, C. D.; FITTER, A. H. An arbuscular mycorrizal fungi accelerates decomposition and acquires nitrogen directiy from organic material. Nature, 413(20):297299, 2001.

HUERTA, S. A. Comparacion de métodos de laboratorio y de campo para medir el area del cafeto. Cenicafé, 13(1):33-42, 1962.

KONRAD, M. L. F. et al. Resposta do cafeeiro á inoculação de fungos micorrízicos arbusculares, em Latossolo Vermelho de cerrado. Bioscience Journal, 30(4):933-941, 2014.

MAIA, L. C.; SILVEIRA, N. S. S.; CAVALCANTE, U. M. T. Interaction between arbuscular mycorrhizal fungi and root pathogens. In: RAI, M. K. Handbook of microbial biofertilizers. New York: The Haworth, 2006, p.325-352.

MALAVOLTA, E.; VITTI, G. C.; OLIVEIRA, S. A. Avaliação do estado nutricional das plantas: Princípios e aplicações. 2. ed. Piracicaba: Potafos, 1997. 319p.

MERGULhÃO, A. C. E. S. et al. Caracterização morfológica e molecular de fungos micorrízicos arbusculares isolados de áreas de mineração de gesso, Araripina, PE, Brasil. Hoehnea, 3(41):393-400, 2014.

MOHAN, J. E. et al. Mycorrhizal fungi mediation of terrestrial ecosystem responses to global change: Mini-review. Fungal Ecology, 10:3-19, 2014.

MOREIRA, F. M. S.; SIQUEIRA, J. O. Microbiologia e bioquímica do solo. 2. Edição atualizada e ampliada. Lavras: Editora UFLA, 2006. 729p.

RODRIGUES, L. A.; BARROSO, D. G.; FIGUEIREDO, F. A. M. M. A. Fungos micorrízicos arbusculares no crescimento e na nutrição mineral de mudas de Tectona grandis L. F. Ciência Florestal, 1(28):25-34, 2018.

SAGGIN JÚNIOR, O. J.; SIQUEIRA, J. O. Micorrizas arbusculares em cafeeiro. In: SIQUEIRA, J. O. (Ed.) Avanços em fundamentos e aplicação de micorrizas. Lavras: DCS/ DCF, 1996. p.203-254.

SAGGIN JÚNIOR, O. J.; SIQUEIRA, J. O. Avaliação da eficiência simbiótica de fungos endomicorrízicos para o cafeeiro. Revista Brasileira Ciências do Solo, 19(2):221-228, 1995.

SAS. SAS Software. Version 9.1. CAry, Noth Carolina: SAS Institute Inc., 1999. 
SIQUEIRA, J. O.; COLOZZI FILHO, A. Micorrizasvesículoarbusculares em mudas de cafeeiro. II. Efeito do fósforo no estabelecimento e funcionamento da simbiose. Revista Brasileira de Ciências do Solo, 10(3):207-211, 1986.

SIQUEIRA, J. O. et al. Arbuscular mycorrhizal inoculation and superphosphate application influence plant development and yield of coffee in Brazil. Mycorrhiza, 7(6):293-300, 1998.

SIQUEIRA, J. O. et al. Crescimento de mudas e produção do cafeeiro sob influência da inoculação com fungos micorrízicos e aplicação de superfosfato. Revista Brasileira de Ciência do Solo, 17(1):53-60, 1993.

SIQUEIRA, J. O. et al. Influência de substrato de formação e da micorriza no crescimento de mudas de cafeeiro transplantadas. Pesquisa Agropecuária Brasileira, 30(12):1417-1425, 1995.

TRISTÃO, F. S. M.; ANDRADE, S. A. L.; SILVEIRA, A. P. D. Fungos micorrízicos arbusculares na formação de mudas de cafeeiro, em substratos orgânicos comerciais. Bragantia, 65(4):649-658, 2006. 